\title{
PROTECTION OF SELF-DEVELOPMENT RIGHT FOR CONVICTED CRIMINALS IN THE ENVIRONMENT OF CLASS IIA CORRECTIONAL INSTITUTIONS OF BENGKULU
}

By :

Henny Wins, Antory Royan Adyan, Hamzah Hatrik

\begin{abstract}
The correctional institutions developing nowadays adopts a penal system that is more educating and fostering. Formerly, correctional institutions adhered to a prison system that was more of a punishment for crimes committed by the criminals. In general, fostering the prisoners aims to make prisoners to be fully human through the strengthening of faith (mental endurance) as well as to foster the prisoners to be able to integrate naturally in prison and in a wider life (community) after serving their convictions. This study on the protection of selfdevelopment right for convicted criminals in the environment of class IIA correctional institutions of Bengkulu was an empirical legal research that aimed to find out and to analyze the implementation of protection of self-development right for prisoners as well as to find out and to analyze the obstacles faced in implementing the protection of self-development right for prisoners in the environment of class IIA correctional institutions of Bengkulu. Data sources of this research were primary and secondary data. Data collection methods applied in this study were interviews and documentation. The data processing method used was descriptive qualitative. From the results of the study, it was revealed that: 1) the implementation of the fulfillment of juvenile prisoners' right to obtain education at the class IIA correctional institutions of Bengkulu had not been fully fulfilled. To fulfill the educational process, there are Program Kejar (Kelompok Belajar/Study Group) of Package A (equivalent to elementary school), Package B (equivalent to junior high school), and Package $\mathrm{C}$ (equivalent to high school) as a series of processes for fulfilling the right for education for juvenile prisoners. But the program had not run optimally according to standards set by the government. Most of the juvenile prisoners make self-taught learning; 2) in the implementation of the education process in prisons, there were several factors that become obstacles in its implementation. These factors included the lack of partners to carry out the process of fulfilling the right for education, the facilities available in correctional institutions were inadequate, the limited teaching staffs provided by the local Education Department, lack of supervision on juvenile prisoners if they were pursuing education outside correctional institutions, as well as minimal budget allocations for educational purpose in correctional institutions.
\end{abstract}

\section{Keywords: Protection, Self-Development Right, Prisoners, Correctional Institutions Environment}




\section{A. INTRODUCTION}

\section{Research Background}

Correctional Institution as one of the law enforcement institutions is the estuary of criminal justice that gives the sentence of confinement to the convicted criminals. Penalty against a person is a process of giving punishment to an individual who is legally proven and convincing to have committed an act that is in the contrary to the laws and regulations. ${ }^{1}$ People (individuals) who are sentenced to criminal terms are referred to as convicts. Acts that violate the provisions of laws and regulations are usually referred to as a crime. Crime is often defined as an act that violates the legal norms and social rules that apply in the midst of the society and the state life which is implied on the criminal sanctions given by the state.

The prisoner guidance system with the penitentiary system was first coined by Satjipto Sahardjo, who wanted that not only the community was protected so that they would not re-commit any of the crimes they had committed, but also

1 Yunus, Pembinaan Narapidana dalam Rangka Pencapaian Tujuan Sistem Pemasyarakatan (Studi di Lapas Pemuda Plantungan). Legal Studies Magister Program, Faculty of Law, University of Diponegoro, Semarang, 2012 (Unpblished Thesis), p.5. those who had gone astray were also protected by providing life supplies in the form of skills to them as useful citizens in the community. Satjipto Sahardjos as a reformer in the world of prison put forward the idea of correcting prisoners which includes (1) each person is a social creature, (2) no one lives outside the community and (3) prisoners are only sentenced to lose freedom of movement. So, it needs to be endeavored to be able to have a livelihood. ${ }^{2}$

One of the correctional institutions in Bengkulu City is Correctional Institution Class IIA which is also known by the people by the name "Malabero Rutan" is located in Sumur Meleleh Village, Teluk Segara District. As the provincial capital, the type of correctional institutions available in Bengkulu City are Class I, not Class IIA, because Class IIA prison should be in the regency and municipal capitals as stipulated in the Decree of the Minister of Justice of the Republic of Indonesia No. M. 01. PR. 07. 03 of 1985 concerning Organization and Work Procedures

2 Petrus Irwan Panjaitan \& Samuel Kikilaitety, Lembaga Pemasyarakatan dalam Perspective Sistem Peradilan Pidana, Pustaka Sinar Harapan, Jakarta, 1995, p.13. 
of Correctional Institutions, Article 4 paragraph 1. Class IIA Prison also places male prisoners, female prisoners and correctional students in one coaching building, because prison for women and children is not yet available in Bengkulu City.

Through this research, it will be examined how the implementation of the protection of self-development right for prisoners as a manifestation of the rights that must be given to them as stated in Article 14 paragraph (1) of Law no. 12/1995 concerning Corrections as well as the realization of the correctional principles carried out in the Prison as stated in Article 5 of the Law. Self-development rights for prisoners is also a form of manifestation of Article 12 of Law No. 39/1999 concerning Human Rights. By knowing the implementation of these rights, various constraints faced in the exercise of the self-development right for prisoners will also be identified, whether they originate from prison or from prisoners themselves.

Based on the above background, the author was interested in studying the case and pouring it into a thesis entitled
"Protection of Self-Development Right for Convicted Criminals in the Environment of Correctional Institutions Class IIA of Bengkulu”.

\section{Identification of Problems}

Based on the background described above, the problems identified in this study were as follows:

1. How was the implementation of the protection of selfdevelopment right for prisoners in the Class IIA Correctional Institutions in Bengkulu?

2. What were the obstacles faced in implementing the protection of self-development right for prisoners in the Class IIA Correctional Institutions in Bengkulu?

\section{a. RESEARCH METHODS}

Based on the type of research, this study was a descriptive study. In a qualitative descriptive study, data obtained through interviews are processed with 3 (three) activity plots that occur simultaneously, systemic and interactional, namely:

1. Data reduction, which is the process of selecting, focusing, and transforming rough data from the field. Data reduction functions to classify, direct, and eliminate data 
and information that are considered unnecessary, so that the data collected can produce a good interpretation.

2. Data presentation, which is a collection of organized information that gives the possibility to draw conclusions and take action. In this case the researcher groups the data systematically to make it easier to understand the relationship between its parts in a complete context.

3. Drawing conclusions, namely conclusions from the data that has been presented in the second stage. The process of analyzing data in this study began by examining all data obtained, then were analyzed and drawn conclusions by using descriptive methods. ${ }^{3}$

\section{B. RESULTS AND DISCUSSION}

1. The Implementation of The Protection of Self-Development Right For Prisoners in The Class

IIA Correctional Institutions In

\section{Bengkulu}

The development of the

State Children is focused on education (Article 22 PP No. 31 of 1999). Forms of Fostering State Children include:
1. Children education and character building;

2. General education;

3. Scouting education;

4. Practice skills.

Based on an interview with Aditya Wahyu Rahmadani as the Head of the Registration of the Class II Special Guidance Institution for Children of Bengkulu, the education and coaching process was carried out divided into several stages, namely:

1. Initial Guidance

In this initial guidance, the implementation of activities includes:

a. Community research is used to determine the guidance program. The data obtained were analyzed and concluded by the Community Advisor, then given advice / considerations.

b. After the litmas is made, a guidance program plan is prepared. The implementation of the guidance program is adjusted to the plan drawn up.

c. Evaluation of the implementation of the initial guidance and preparation of the next stage of the guidance plan

2. Advanced Guidance

\footnotetext{
${ }^{3}$ Ibid, p.93.
} 
In the advanced guidance, the attention must be paid to:

a. The implementation of the advanced guidance program is tailored to the needs and problems of the client, confinement to report, home visits and increased guidance to clients.

b. Assessment of the advanced program and the preparation of final guidance.

3. Final Guidance

The final stage of guidance includes:

a. Research and assess the overall results of the implementation of the guidance program

b. Prepare clients for the end of the guidance period

c. Consider the possibility of additional guidance services

d. Preparing a statement of the client's criminal end period in carrying out these stages if there is a client case that needs solving, then a special hearing will be held. The results of the special session can be taken into consideration for further policy. ${ }^{4}$

4 Interview with Aditya Wahyu Rahmadan, staff of the registration section of Class IIA Prison in Bengkulu, December $2^{\text {nd }}, 2019$
The education for child prisoners in Class IIA Prison of Bengkulu City includes formal, non-formal and informal education given directly by the Community Guidance. The education provided are:

\section{Formal Education}

The formal education is a structured and tiered education pathway consisting of basic, secondary and higher education. In Class IIA Prison of Bengkulu City there are children who were still active as school students, when interviewed by Ani Mardijah as prison officers ${ }^{5}$ said that "for a criminal child who is still active as a school student, when the child is named a suspect from the correctional institution immediately gives a letter to the school to coordinate how the fulfillment of his educational rights.

2. Non-Formal Education

The implementation of compulsory education in the nonformal education pathway is carried out through package A,B,C programs and other equivalent forms. In Government Regulation 
Number 32 of 1999 concerning Corrections Requirements and Procedures for Correctional Guidance Members, it is stated that in each correctional facility, education and teaching activities for prison inmates and education and teaching in prisons are carried out according to the applicable curriculum in educational institutions.

Although a convicted person loses his independence, there are rights of child prisoners who were still protected in the Indonesian penitentiary system, namely the right to education and teaching. To find out whether the child's right to education has been fulfilled in prison, an interview was conducted with staff for Class IIA Prison of Bengkulu City.

3. Informal Education

a. Religious Education

The education is a very common word. Therefore, it can be said that everyone was familiar with the term education.

Suhartadi ${ }^{6}$ explained that " the religious education at Class

6 Interview with Suhartadi, Community Assistant from Class IIA Prison on $28^{\text {th }}$ of November 2018
IIA prison of Bengkulud City was held once a week on Thursday by coordinating with the Ministry of Religion in Bengkulu City as well as nonMuslim filmmakers who are Christian and Catholic in collaboration with the church. The religious education must be attended by all prisoners ".

\section{b. Vocational Education}

The fostering skills is the ability needed to improve one's functional abilities and attitudes to be able to solve various complex life problems in the fabric of people's lives. The skills education program for inmates is expected to provide a prisoner with the knowledge, skills and practical functional abilities as well as a change in attitude to work and try to be independent, open up jobs and businesses also take advantage of the opportunities they have, thereby increasing the quality of their welfare.

There are several obstacles in running this program. One of them is a criminal child unable to provide the last diploma. The diploma is needed as a 
file that must be completed to take the national exam.

\section{Obstacles In Carrying Out The} Process Of Fulfilling The Right To Get Education At The Class IIA

\section{Prison of Bengkulu}

The Class 1 prison (Lapas) of Bengkulu City is a place intended to accommodate adult inmates. The system of coaching is set up based on the needs of adult inmates to fulfill their rights and carry out their obligations as an adult inmate. But in reality, in the Class IIA Prison of Bengkulu City also accommodates child inmates and detainees. According to the applicable laws and regulations, child convicts must be placed in a correctional facility for children. For the Bengkulu area, the Child Prison is located in the city of Bengkulu, namely the Class IIA prison for Children in Bengkulu. This prison is intended for child convicts in Bengkulu. The separation of places like this is very important to prevent child inmates from the influence of the association of adult prisoners which can have a negative impact on the personality development of child prisoners.

The Class IIA Prison of Bengkulu City itself, there are a number of child convicts serving their sentences in prison which were provided for inmates today. For this purpose, the prisoners provide a special Block for children to be separated from adult prisoners. However, this still violates established procedures.

There are several reasons why child prisoners were placed in Class IIA Prison of Bengkulu City. Wilham, S. H ${ }^{7}$ explained that the main reason that caused children to be placed in prison is about psychological problems of children. Where the child needs his parents as a companion to maintain the child's emotional stability. The children always need a visit from parents and the closest people to accompany him in difficult times like this. If he (the child) is placed in prison of Bengkulu, it is likely that the child's parents will be slightly constrained to carry out routine assistance to his child. This is due to the distance traveled. Because most of the child convicts contained in Class IIA prison of Bengkulu City are from Bengkulu City.

Basically, the number of child convicts contained in Class IIA Prison of Bengkulu City is only 17 peoples, but because there are also prisoners held in custody in this prison, the number of children in reaching hundreds. With

\footnotetext{
${ }^{7}$ Interview with Andi Muhamad Hamka, S.Hi., M.Hi., as a staff section of social guidance from the Class IIA Prison of Bengkulu City, June $1^{\text {st }}, 2014$
} 
such numbers, more educators are needed to be able to provide equitable education for all children in prison.

According to the applicable regulations, the Head of Prison can cooperate with government agencies whose scope of work includes the field of Education and Culture, and / or community agencies engaged in education and teaching. But based on the reality now it has not been done well. Many educators such as teachers are reluctant to attend prison in the context of providing education to child prisoners for certain reasons. This situation can hamper children's education in an effort to shape the character of the foundation of thinking, as well as academic abilities for child prisoners. This of course should get more attention from the prison and the Office of Education and Culture, given the very importance of education for children.

1. Lack of budget supply for education. The budget for education is one of the supporting factors in the education process of juveniles in prison. This is also something urgent. There is a close relationship between the budget and costs with the fulfillment of other needs for the smooth running of the education process. Inside Prison, personal education can be done outside Prison by first fulfilling the requirements set by Prison. For example, to get outside education, there are extra benefits that must be paid by parents. The fee is used to facilitate children in doing the process.

2. Lack of Guards for prisoners. Escort for prisoners must be done if the juveniles carry out the education process outside of prison. This escort is aimed at supervising juveniles in conducting education outside the prison, so that they do not commit wrong actions or actions outside of the stipulated regulations, such as fleeing, committing a crime, and so forth.

3. Lack of work partners in an effort to fulfill the rights of child prisoners to get education in the Penitentiary. Lack of participation from related institutions such as the Ministry of Education and Culture in this case the supply of educators. Work partners are urgently needed to facilitate the needs of Juveniles. Prison always welcomes the willingness of teachers. Not only teachers, but also active participation from various child activist elements and other institutions related to juveniles are 
needed to make the program and the implementation of education in prison success. If many agencies or working partners can be directly involved in fulfilling this right, Prison will be greatly assisted in carrying out the process of fulfilling the education.

4. Low awareness of the community, regional governments both provincial and city / district and community organizations towards the future of children's prisoner education in Class IIA Penitentiary Bengkulu. This situation is the latest condition of Class 1 Penitentiary of Bengkulu City. This situation can make the fulfillment of children's rights in prison neglected. Child prisoners are used to self-taught learning and are based on available reading material. Quality of Education for children, which is none other than the next generation of the nation in the future should be questioned. Education and coaching conducted in prison will greatly affect the development of children in the future. Therefore, it must be matters that education should always be made the top priority in efforts to improve the quality of the nation's intelligence going forward.
From the results of the study showed that most children prisoners are lack education. That is because there are some juveniles who are unable to read or write. Most juveniles only learn by selftaught and practice guidance material by the officers. As a juvenile, Yusran ${ }^{8}$ also added that "in prison there are times or schedules set by officers to carry out the education process. But the education process does not cover all education as is found in schools in general.

Here we often learn about religion such as the reading Qur'an, praying, and excercising. We haven't been able to get technology lessons such as computers because maybe the facilities aren't here yet ".

The lack of availability of teaching staff, especially in academic education for juveniles in Class 1 Penitentiary in Bengkulu City, must be immediately addressed. Basic education and academic knowledge are urgently needed by juveniles to broaden their horizons in thinking.

Education and teaching in prisons should be organized according to the curriculum applicable to educational institutions that are equal. But due to the obstacles to realize the program, the

\footnotetext{
${ }^{8}$ Interviewed with Yusran, A child prisoner of Penitentiary Class IIA of Bengkulu City
} 
educational activities in prison have been carried out with modest facilities and infrastructure.

For the Penitentiary of Class IIA of Bengkulu City, the fulfillment of the right to get education for juvenilse is continuously carried out, so that it can run optimally. However, this cannot be delegated as a whole by the implementation system to Prison. In the government's regulations, it does not fully explain the technical guidelines for the implementation of education.

According to Gunawan ${ }^{9}$, this also becomes a major obstacle in the implementation of the fulfillment of the rights of education for juveniles.

Prison as the task executor tries as much as possible to carry out the fulfillment, one of them is by synchronizing the teaching methods of education with the guidance process that is in the prison. Even though this is still considered to be not optimal, this is a maximum effort that can be done.

Education is a mean that supports the country's success in making children of the country a member of society. Prison is very instrumental in fostering and educating prisoners to be better.

\footnotetext{
Interviewed with Gunawan,Amd.IP,S.Sos.,S.H.,M.Si, Section Head of Community Guidance Penitentiary of Class IIA of Bengkulu City
}

What really very important to be fostered is the personal of juveniles, raising self-esteem and developing a sense of responsibility to adjust to a peaceful and prosperous life in society, so that they become a highly personal and moral person.

\section{CLOSING}

\section{Conclusions}

a. Implementation of the fulfillment of the right of juveniles to get education in Correctional Institutions of Class IIA of Bengkulu has not been fully fulfilled. However, efforts to implement education continue to be done as well as possible given the very urgency of education for a person (child) despite undergoing a criminal period. The right to education is something that must be fulfilled because it has been regulated in Government Regulation. In $\mathrm{P}$ Correctional Institutions of Class IIA of Bengkulu, to fulfill the educational process, there is a Study Group of Paket $A$ (equivalent to Elementary School), Paket $B$ (equivalent to Junior High School), and Paket C (equivalent to High School) as a series of processes to fulfill the right to get education for juveniles. But the program has not run 
optimally according to standards set by the government. Most juveniles make self-taught learning. In implementing the Pursuing education package, the Prison collaborates with the Department of Education. Coaching and education are carried out according to a schedule that has been set by the Prison. For the teaching process, Prison collaborates with the Department of Education, especially for the provision of teaching staff.

b. In the implementation of the education process in prisons, there are several factors that become obstacles in its implementation. These factors include the lack of work partners to carry out the process of fulfilling the right to education, the facilities available in Prison are inadequate, the limited teaching staff provided by the Department of Education, escort to juveniles when pursuing education outside Prisons, as well as minimum budget allocations. In addition there are also obstacles from the juridical aspect. There are no implementing regulations that specifically regulate the implementation of formal school education for juveniles in prison.
In Government Regulation No. $32 / 1999$ it only explains the obligation to carry out formal education in prisons, but the technical implementation to support these activities is not regulated in detail. This situation makes it difficult for the penitentiary to implement the regulation.

\section{Suggestions}

Based on the above conclusions, the suggestions that can be submitted by the author are as follows:

a. To overcome the problems that occur in Correctional Institutions of Class IIA of Bengkulu, especially in the process of implementing education for juveniles, a direct role from the local government must be required in this case the Ministry of Law and Human Rights to evaluate the work program planning that has been made. The oversight function of all educational and coaching programs is also important. Supervision is carried out in an effort to oversee the programs carried out in prisons. It is important to know the problems that 
can hinder the survival of child prisoners' rights, especially regarding education. Prison as facilitators must also provide the needs of children in the form of adequate facilities and infrastructure to support children's education in Correctional Institutions. In addition, Government Regulations are very much needed in terms of determining technical instructions and implementing instructions for conducting education based on the curriculum conducted in Correctional Institutions of Class IIA of Bengkulu. This is very important to do, so that the task implementers in the field have a basic handle and benchmark in doing so. With these two things, the implementers of the education program in the Correctional Institutions do not lose their direction and have a clear vision in conducting the teaching process. b. Partners are urgently needed by the Prison to provide or facilitate the education and teaching process in Correctional Institutions of Class IIA of Bengkulu. Collaboration with these parties can help overcome obstacles in prison. The Department of Education and Culture must also play an active role in facilitating the needs of juveniles. Participation from community organizations, college students, and child activists is also needed in this process given the very importance of education for juveniles, especially in Correctional Institutions of Class IIA of Bengkulu.

\section{REFERENCES}

A. Gunawan Setiardja. 1993. Hak-Hak Asasi Manusia Berdasarkan Ideologi Pancasila. Yogyakarta: Kanisius.

Adi Sudjatno, Negara tanpa Penjara: Sebuah Renungan, Montas Ad, Jakarta, 2002

Adi Sudjatno, Sistem Pemasyarakatan Indonesia Membangun Manusia Mandiri, Departemen Hukum dan Hak Asasi Manusia (HAM) Republik 
Indonesia, Direktorat Jenderal Pemasyarakatan, Jakarta, 2004.

Andi Hamzah, Sistem Pidana dan Pemidanaan di Indonesia, Pradnya Paramitha, Jakarta, 1993.

Bambang Poernomo. 1986. Pelaksanaan pidana penjara dengan sistem pemasyarakatan. Yogyakarta: Liberty Yogyakarta.

C. I. Harsono Hs, Sistem Baru Pembinaan Narapidana, Penerbit Djambatan, Jakarta, 1995

Darwan Print. 2003. Hukum Anak Indonesia. Bandung:PT. Citra Aditya Bakti.

Didin Sudirman,Reposisi dan Revitalisasi Pemsayarakatan dalam Sistem Peradilan Pidana di Indonesia, Departemen Hukum dan Hak Asasi Manusia (HAM) Republik Indonesia, Pusat Pengkajian dan Pengembangan Kebijakan, Jakarta, 2007

Dwidja Priyatno, Sistem Pelaksanaan Pidana Penjara di Indonesia, Cetakan Ketiga, Refika Aditama, Bandung, 2013.

Dwidja Priyatno. 2006. Sistem Pelaksanaan Pidana Penjara Di Indonesia. Bandung: PT. Refika Aditama. Gasti
Ratnawati. Pola Pembinaan NAPI Anak sebagai Salah Satu Upaya Pemenuhan Kebutuhan Pendidikan di Lembaga Pemasyarakatan Anak. Malang. PDF.

Hesly E. Marentek, Pembinaan terhadap Warga Binaan dalam Lembaga Pemasyarakatan Ditinjau dari Perspektif Peraturan Perundangundangan yang Berlaku, Jurnal Lex Crimen, Vol. IV, No. 8, Oktober 2015.

I Gede Ardian Paramandika, Pembinaan terhadap Narapidana di Lembaga Pemasyarakatan Klas IIA Denpasar. [Jurnal] Program Magister Ilmu Hukum, Fakultas Hukum, Universitas Udayana, Denpasar, 2012: 1-6.

Maulana Hassan Wadong. 2000. Pengantar Advokasi dan Perlindungan Anak. Jakarta: PT. Gramedia.

Naney Nelson Knupfer \& Hilary McLellan, Descriptive research methodologies, Kanzas State University Press, Manhattan, USA, 1990,

Peter Mahmud Marzuki, Penelitian Hukum, Edisi Revisi, Cetakan Keenam, Kencana: Prenada Media Group, Jakarta, 2010 